\title{
Experimental Results and Integrated Modeling of Bacterial Growth on an Insoluble Hydrophobic Substrate (Phenanthrene)
}

\author{
Adam, Iris K. U.; Rein, Arno; Miltner, Anja; Fulgencio, Ana C. D.; Trapp, Stefan; Kaestner, Matthias
}

Published in:

Environmental Science \& Technology (Washington)

Link to article, DOI:

$10.1021 /$ es500004z

Publication date:

2014

Document Version

Publisher's PDF, also known as Version of record

Link back to DTU Orbit

Citation (APA):

Adam, I. K. U., Rein, A., Miltner, A., Fulgencio, A. C. D., Trapp, S., \& Kaestner, M. (2014). Experimental Results and Integrated Modeling of Bacterial Growth on an Insoluble Hydrophobic Substrate (Phenanthrene).

Environmental Science \& Technology (Washington), 48(15), 8717-8726. https://doi.org/10.1021/es500004z

\section{General rights}

Copyright and moral rights for the publications made accessible in the public portal are retained by the authors and/or other copyright owners and it is a condition of accessing publications that users recognise and abide by the legal requirements associated with these rights.

- Users may download and print one copy of any publication from the public portal for the purpose of private study or research.

- You may not further distribute the material or use it for any profit-making activity or commercial gain

- You may freely distribute the URL identifying the publication in the public portal 


\title{
Experimental Results and Integrated Modeling of Bacterial Growth on an Insoluble Hydrophobic Substrate (Phenanthrene)
}

\author{
Iris K. U. Adam, ${ }^{\dagger, \S}$ Arno Rein, ${ }^{*}, \ddagger, \S, \perp$ Anja Miltner, ${ }^{\dagger}$ Ana C. D. Fulgêncio, ${ }^{\dagger}$ Stefan Trapp, ${ }^{\ddagger} \|$ \\ and Matthias Kästner ${ }^{\dagger}, \|$
${ }^{\dagger}$ Department of Environmental Biotechnology, Helmholtz-Centre for Environmental Research-UFZ, Permoserstr. 15, 04318 Leipzig, Germany \\ ${ }^{\ddagger}$ Department of Environmental Engineering, Technical University of Denmark, Miljøvej bd. 113, DK-2800 Kgs. Lyngby, Denmark
}

\section{Supporting Information}

ABSTRACT: Metabolism of a low-solubility substrate is limited by dissolution and availability and can hardly be determined. We developed a numerical model for simultaneously calculating dissolution kinetics of such substrates and their metabolism and microbial growth (Monod kinetics with decay) and tested it with three aerobic phenanthrene (PHE) degraders: Novosphingobium pentaromativorans US6-1, Sphingomonas sp. EPA505, and Sphingobium yanoikuyae B1. PHE was present as microcrystals, providing non-limiting conditions for growth. Total PHE and protein concentration were tracked over 6-12 days. The model was fitted to the test results for the rates of dissolution, metabolism, and growth. The strains showed similar efficiency, with $v_{\max }$ values of $12-18 \mathrm{~g} \mathrm{dw} \mathrm{g}^{-1}$ $\mathrm{d}^{-1}$, yields of $0.21 \mathrm{~g} \mathrm{~g}^{-1}$, maximum growth rates of $2.5-3.8 \mathrm{~d}^{-1}$, and decay rates of $0.04-0.05 \mathrm{~d}^{-1}$. Sensitivity analysis with the model shows that (i) retention in crystals or NAPLs or by sequestration competes with biodegradation, (ii) bacterial growth conditions (dissolution flux and resulting chemical activity of substrate) are more relevant for the final state of the system than the initial biomass, and (iii) the desorption flux regulates the turnover in the presence of solid-state, sequestered (aged), or NAPL substrate sources.

\section{INTRODUCTION}

Polycyclic aromatic hydrocarbons (PAH) are hydrophobic compounds with a strong tendency toward absorption on surfaces in aqueous systems that undergo no or only slow decomposition in the environment. ${ }^{1} \mathrm{PAH}$ are metabolized by a large number of enzymes in bacteria, fungi, and algae and by cytochrome P-450 monooxygenases in eukaryotic cells. ${ }^{2}$ Cometabolic transformation of these compounds is found in all organisms, whereas complete metabolization leading to biomass and carbon dioxide is described only for bacteria. Microbial degradation of PAH is well-documented in numerous reviews. ${ }^{1,3-13}$ In comparison to the general published results on $\mathrm{PAH}$ biodegradation, data on the growth kinetics of PAHdegrading organisms are rare. ${ }^{14-18}$ The biodegradation of the low-soluble PAH is often limited by the diffusive flux to the microbes, and this is the reason for the pseudolinear growth of degraders often found in experiments. ${ }^{19,20}$ Therefore, reliable data for kinetic parameters such as growth rates $(\mu)$ and halfsaturation constants $\left(K_{\mathrm{M}}\right)$ are not easily available for PAHdegrading strains and cannot be derived solely from growth curves. ${ }^{21}$ The Best equation, which balances diffusive flux to the bacterium with metabolic flux in a steady state, has been applied in order to describe the kinetics of metabolism and mass transfer from solids to bacteria. ${ }^{15,18,19}$
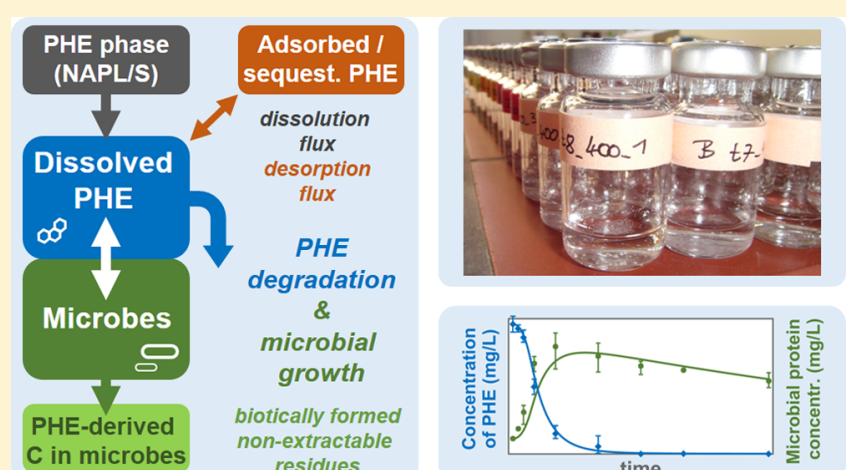
-extractable residues
Recently, a model for fast and slow adsorption ("aging”) was fused with a biodegradation model that calculates degradation and growth kinetics of microbes. ${ }^{22}$ The model includes dissolution from a nonaqueous phase (source term), adsorption with two different rates, and Michaelis-Menten kinetics for metabolism (sink term) with coupled Monod kinetics plus a decay term for bacterial growth and carbon turnover for the simulation of biotic formation of nonextractable residues. ${ }^{23}$ This leads to a set of ordinary non-linear differential equations that are solved numerically.

In two recent studies, degradation of phenanthrene (PHE) in soil suspension with strain Sphingomonas sp. 10-1 was investigated, whereby the flux kinetics was inversely modeled with a reduced version of the above model. ${ }^{24,25}$ The experimental setup with high bacterial numbers and low PHE concentrations led to non-growth conditions where only decay rate constants $b$ could be calibrated. Therefore, very little kinetic data for various $\mathrm{PAH}$ degrader bacteria has been

Received: January 8, 2014

Revised: $\quad$ May 23, 2014

Accepted: June 26, 2014

Published: June 26, 2014 
Table 1. Phenanthrene-Degrading Strains Used in the Present Experiments

\begin{tabular}{|c|c|c|c|}
\hline & Sphingobium yanoikuyae B1 & Sphingomonas sp. EPA505 & Novosphingobium pentaromativorans US6-1 \\
\hline DSM no. & 6900 & 7526 & 17173 \\
\hline Gram staining & negative & negative & negative \\
\hline $\begin{array}{l}\text { morphology (diameter by } \\
\text { length) }\end{array}$ & rod-shaped $(0.7-1.1$ by $1-3 \mu \mathrm{m})$ & rod-shaped ( 0.5 by $1.5 \mu \mathrm{m})$ & rod-shaped $(0.36-0.45$ by $0.97-1.95 \mu \mathrm{m})$ \\
\hline motility & \pm & \pm & \pm \\
\hline isolated from & polluted stream, USA & $\begin{array}{l}\text { sandy soil creosote waste site, } \\
\text { USA }\end{array}$ & estuarine sediment, Korea \\
\hline PAH mineralization ${ }^{a}$ & Ant, Naph, Phen & Ant, Be[b]fluo, Flu, Naph, Phen & $\begin{array}{l}\text { Ant, Be[a]ant, Be[a]pyr, Be[b]flu, Chr, Flu, Fluo, } \\
\text { Phen, Pyr }\end{array}$ \\
\hline chromosome sequenced & & & contig level \\
\hline plasmid(s) sequenced & & & 2 \\
\hline references & $36,41-43$ & $44-46$ & 47,48 \\
\hline
\end{tabular}

available until now for the prediction of PAH turnover with this unified model of sorption and metabolism.

The goals of the present work were (i) to study the kinetics of aerobic PHE degradation by three known and well-described bacteria (one with genome sequenced) and their resulting growth at varying substrate concentrations, (ii) to provide the real growth and yield parameters for these bacteria by a combination of experiments and model calibration, and (iii) to determine and interpret differences in the kinetic parameters for dissolution and metabolism.

\section{MATERIALS AND METHODS}

Strains and Culture Conditions. The three strains Novosphingobium pentaromativorans US6-1, Sphingomonas sp. EPA505, and Sphingobium yanoikuyae B1 were enriched from various PAH contaminated sites and are well-described (Table 1). They were chosen on the basis of their rapid PHE degradation plus growth kinetics in liquid cultures.

The strains were precultivated on mineral medium (MM) with vitamins (Brunner, DSMZ no. 462). ${ }^{26}$ The MM consists of $\mathrm{Na}_{2} \mathrm{HPO}_{4} 2.44 \mathrm{~g} \mathrm{~L}^{-1}, \mathrm{KH}_{2} \mathrm{PO}_{4} 1.52 \mathrm{~g} \mathrm{~L}^{-1},\left(\mathrm{NH}_{4}\right)_{2} \mathrm{SO}_{4} 0.5 \mathrm{~g}$ $\mathrm{L}^{-1}, \mathrm{MgSO}_{4} \cdot 7 \mathrm{H}_{2} \mathrm{O} 0.2 \mathrm{~g} \mathrm{~L}^{-1}, \mathrm{CaCl}_{2} \cdot 2 \mathrm{H}_{2} \mathrm{O} 0.05 \mathrm{~g} \mathrm{~L}^{-1}, 10 \mathrm{~mL}$ $\mathrm{L}^{-1}$ trace element solution SL-4 (containing per L: EDTA $0.5 \mathrm{~g}$, $\left.\mathrm{FeSO}_{4} \cdot 7 \mathrm{H}_{2} \mathrm{O} 0.2 \mathrm{~g}\right)$, and $100 \mathrm{~mL} \mathrm{~L}^{-1}$ trace element solution SL-6, (containing per L: $\mathrm{ZnSO}_{4} \cdot 7 \mathrm{H}_{2} \mathrm{O} 0.1 \mathrm{~g}, \mathrm{MnCl}_{2} \cdot 4 \mathrm{H}_{2} \mathrm{O} 0.03$ g, $\mathrm{H}_{3} \mathrm{BO}_{3} 0.3 \mathrm{~g}, \mathrm{CoCl}_{2} \cdot 6 \mathrm{H}_{2} \mathrm{O} 0.2 \mathrm{~g}, \mathrm{CuCl}_{2} \cdot 2 \mathrm{H}_{2} \mathrm{O} 0.01 \mathrm{~g}, \mathrm{NiCl}_{2}$. $\left.6 \mathrm{H}_{2} \mathrm{O} 0.02 \mathrm{~g}, \mathrm{Na}_{2} \mathrm{MoO}_{4} \cdot 2 \mathrm{H}_{2} \mathrm{O} 0.03 \mathrm{~g}\right)$ ), and $2.5 \mathrm{~mL} \mathrm{~L}^{-1}$ vitamin solution (containing per L: $p$-aminobenzoate $10 \mathrm{mg}$, biotin $2 \mathrm{mg}$, nicotinic acid $20 \mathrm{mg}$, thiamine- $\mathrm{HCl} \cdot 2 \mathrm{H}_{2} \mathrm{O} 10 \mathrm{mg}$, Ca-pantothenate $5 \mathrm{mg}$, pyridoxamine $50 \mathrm{mg}$, vitamin $\mathrm{B}_{12} 20$ $\mathrm{mg})$.

PHE (98\% purity, Sigma-Aldrich, Saint Louis, USA) was provided as the sole source of carbon and energy by adding 5 , $12.5,25,50,100$, or $200 \mu \mathrm{L}$ of PHE dissolved in acetone (4 mg $\left.\mathrm{mL}^{-1}\right)$ to the cultivation flasks, shaking the vials in order to cover the bottom surface. The acetone was then allowed to evaporate fully in order to cover the inside with a PHE microcrystal layer prior to adding the $\mathrm{MM}$, resulting in final medium concentrations of $10,25,50,100,200$, and $400 \mathrm{mg}$ $\mathrm{L}^{-1}$. This method, as described by Mutnuri et al., ${ }^{27}$ is intended to enable nonlimited growth on PHE.

Experimental Setup. In order to overcome the inhomogeneities of $\mathrm{PAH}$ cultures with suspension concentrations above water solubility, a setup of destructively sampled small vials (10 mL with $2 \mathrm{~mL} \mathrm{MM}$ ) was chosen (mini-culture approach). Vials containing $1800 \mu \mathrm{L}$ of $\mathrm{MM}$ were allowed to equilibrate overnight and were inoculated to an initial optical density of 0.01 at $560 \mathrm{~nm}$ by adding $200 \mu \mathrm{L}$ of a preculture grown under similar conditions to late exponential phase. Each vessel was completely sampled at the respective sampling points and analyzed in total. The experiment was performed in six replicates for each concentration and time point in order to provide triplicates for separate quantification of biomass and PHE. The mini-cultures were incubated at $30^{\circ} \mathrm{C}$, shaken at 135 rpm, and harvested as follows: for $N$. pentaromativorans, after 0 , $4,8,12,24,36,48,96$, and $144 \mathrm{~h}$ of incubation for initial 10, 25, and $50 \mathrm{mg} \mathrm{L}^{-1}$ PHE concentrations and after 0, 6, 12, 24, 48, $96,144,192$, and $288 \mathrm{~h}$ for initial 100,200 , and $400 \mathrm{mg} \mathrm{L}^{-1}$ PHE concentrations; and for S. yanoikuyae and Sphingomonas sp., after $0,4,8,12,24,30,36,48$, and 96 h for initial 10, 25, and $50 \mathrm{mg} \mathrm{L}^{-1} \mathrm{PHE}$ concentrations and after $0,6,12,24,48$, $72,96,192$, and $288 \mathrm{~h}$ for initial 100, 200, and $400 \mathrm{mg} \mathrm{L}^{-1} \mathrm{PHE}$ concentrations.

Protein Analysis. For monitoring bacterial growth, protein concentration was measured photometrically in 96 well plates applying the Bradford protein assay (BIO RAD Protein Assay, Bio-Rad Laboratories, Munich, Germany) using a Victor2Multilabel Counter (1420, Wallac Oy, Turku, Finland). A $160 \mu \mathrm{L}$ culture sample was thoroughly mixed with $40 \mu \mathrm{L}$ undiluted Bradford dye solution and quantified in triplicates against bovine serum albumin ( $\geq 98 \%$ purity, Carl Roth, Karlsruhe, Germany) as the calibration standard.

PAH Analysis. For tracking the PAH consumption the mini-cultures were extracted two times with $2 \mathrm{~mL}$ of hexane, with fluorene ( $98 \%$ purity, Sigma-Aldrich, Saint Louis, USA) as internal standard. PHE was quantified by means of a gas chromatograph (7890A, Agilent Technologies, Santa Clara, California) equipped with a BPX5 column $(30 \mathrm{~m} \times 0.25 \mathrm{~mm}$ i.d., $0.25 \mu \mathrm{m}$ film, SGE Analytical Science, Melbourne, Australia) and coupled to a mass spectrometer (5975C, Agilent Technologies, Santa Clara, California). The GC oven temperature was programmed to initial $40{ }^{\circ} \mathrm{C}(2 \mathrm{~min}$ hold $)$, then heat to $180{ }^{\circ} \mathrm{C}$ ( 2 min hold) at $40{ }^{\circ} \mathrm{C} \mathrm{min}-1$, to $240{ }^{\circ} \mathrm{C}(2 \mathrm{~min}$ hold) at $5{ }^{\circ} \mathrm{C} \mathrm{min}-1$, and to a final temperature of $300{ }^{\circ} \mathrm{C}(5$ min hold) at $15{ }^{\circ} \mathrm{C} \mathrm{min}-1$ with a helium flow of $1.5 \mathrm{~mL} \mathrm{~min}^{-1}$ (based on ref 28). The injector was set to $280{ }^{\circ} \mathrm{C}$. The MS was operated in the electron impact ionization mode at $70 \mathrm{eV}$. The source temperature was set to $230{ }^{\circ} \mathrm{C}$, the quadrupole temperature to $150{ }^{\circ} \mathrm{C}$. Full scans were acquired in the $\mathrm{m} / \mathrm{z}$ range $40-500$.

Model. The model consists of a set of ordinary differential equations (spatial dependencies were not occurring) with 

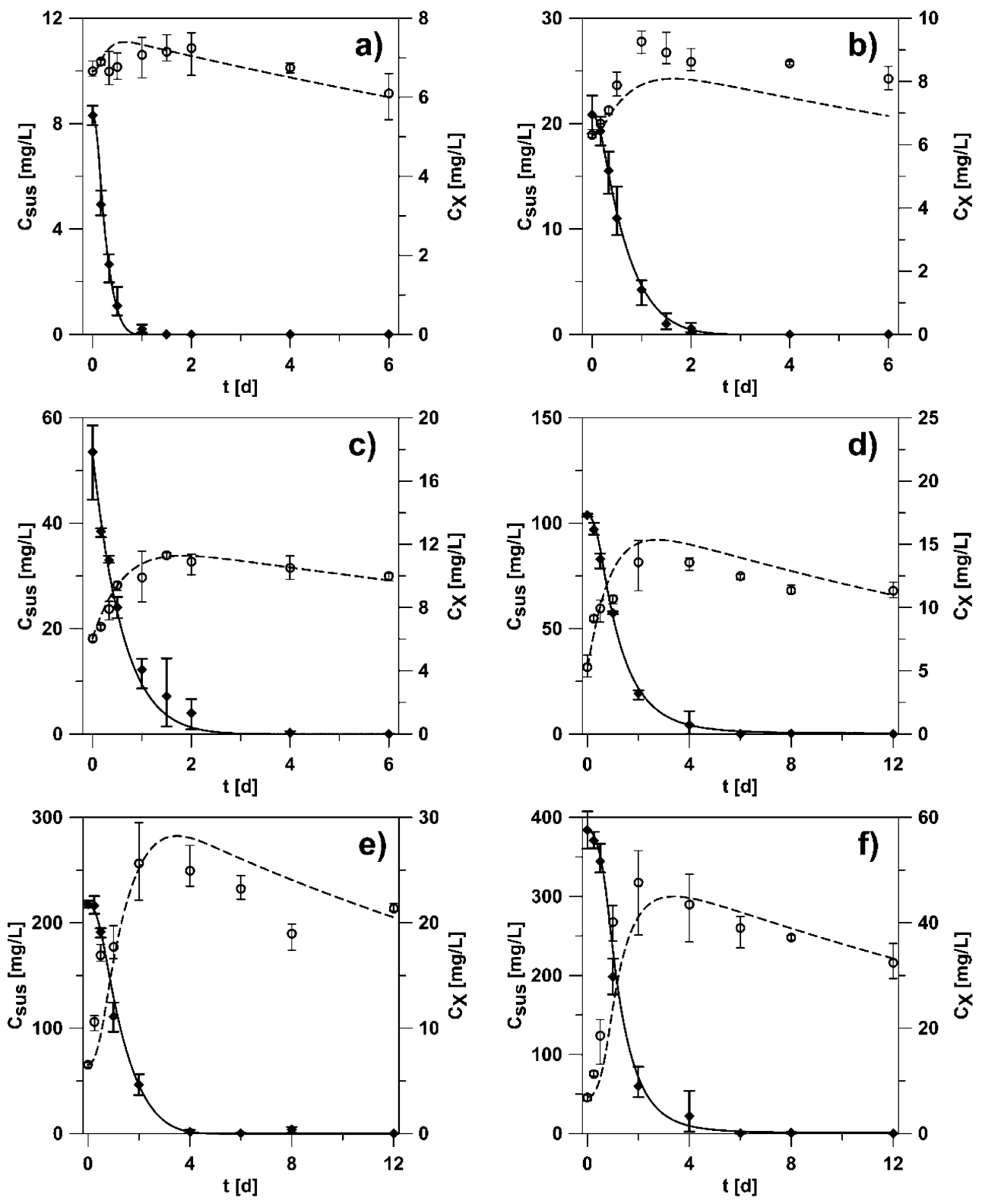

Figure 1. Experiments with $N$. pentaromativorans: phenanthrene concentration in suspension $C_{\text {Sus }}(-\downarrow-$, straight lines, diamonds) and protein concentration $C_{\mathrm{X}}$ (- - O- - dashed lines, circles), measured (data points) versus modeled (curves). Experiments with nominal initial phenanthrene concentrations: (a) $C_{0}=10 \mathrm{mg} \mathrm{L}^{-1}$, (b) $C_{0}=25 \mathrm{mg} \mathrm{L}^{-1}$, (c) $C_{0}=50 \mathrm{mg} \mathrm{L}^{-1}$, (d) $C_{0}=100 \mathrm{mg} \mathrm{L}^{-1}$, (e) $C_{0}=200 \mathrm{mg} \mathrm{L}^{-1}$, (f) $C_{0}=400 \mathrm{mg} \mathrm{L}^{-1}$. Error bars indicate minimum and maximum (3 replicates).

chemical and bacterial mass as state variables. Combined modeling was carried out for the dissolution of PHE from microcrystals into water and for microbial biodegradation. Dissolution, i.e., the diffusive flux from PHE phase into water was considered as

$$
\frac{\mathrm{d} m_{\mathrm{ph}}}{\mathrm{d} t}=P A_{\mathrm{ph}}\left(S-C_{\mathrm{W}}\right)
$$

where $m_{\mathrm{ph}}(\mathrm{g})$ is the PHE mass, $t(\mathrm{~d})$ is time, $P\left(\mathrm{~m} \mathrm{~d}^{-1}\right)$ is the permeability or mass transfer coefficient, $A_{\mathrm{ph}}\left(\mathrm{m}^{2}\right)$ is the surface area of PHE phase, $S\left(\mathrm{~g} \mathrm{~m}^{-3}\right)$ is water solubility of PHE, and $C_{\mathrm{W}}\left(\mathrm{g} \mathrm{m}^{-3}\right)$ is the freely dissolved concentration (synonym chemical activity) of PHE in water.

The metabolism of substrate by microbes is given by the Michaelis-Menten equation:

$$
\frac{\mathrm{d} m_{\mathrm{M}}}{\mathrm{d} t}=\frac{v_{\mathrm{max}} C_{\mathrm{W}}}{K_{\mathrm{M}}+C_{\mathrm{W}}} X=v X
$$

where $v_{\max }$ is the maximum removal rate ( $\mathrm{g}$ substrate $\mathrm{g}^{-1}$ bacteria $\left.\mathrm{d}^{-1}\right), K_{\mathrm{M}}$ is the half-saturation constant ( $\mathrm{g}$ substrate $\left.\mathrm{m}^{-3}\right)$, and $X(\mathrm{~g})$ is the microbial mass. ${ }^{29,30}$ Microbial growth is described by the Monod equation (plus decay term):

$$
\frac{\mathrm{d} X}{\mathrm{~d} t}=\left(\frac{\mathrm{d} m_{\mathrm{M}}}{\mathrm{d} t}-X r\right) Y
$$

where $Y$ ( $\mathrm{g}$ bacteria $\mathrm{g}^{-1}$ substrate) is yield, and $r$ ( $\mathrm{g}$ substrate $\mathrm{g}^{-1}$ bacteria $\left.\mathrm{d}^{-1}\right)$ is maintenance given as $r=b / Y$, with $b\left(\mathrm{~d}^{-1}\right)$ being a first-order rate constant describing the decline of microbial activity with time; the term $\mathrm{d} m_{\mathrm{M}} / \mathrm{d} t$ (g substrate $\mathrm{d}^{-1}$ ) describes metabolic flux, and the term $X$ times $r$ ( $\mathrm{g}$ substrate $\mathrm{d}^{-1}$ ) describes microbial maintenance needs. ${ }^{15,18,31}$ These 

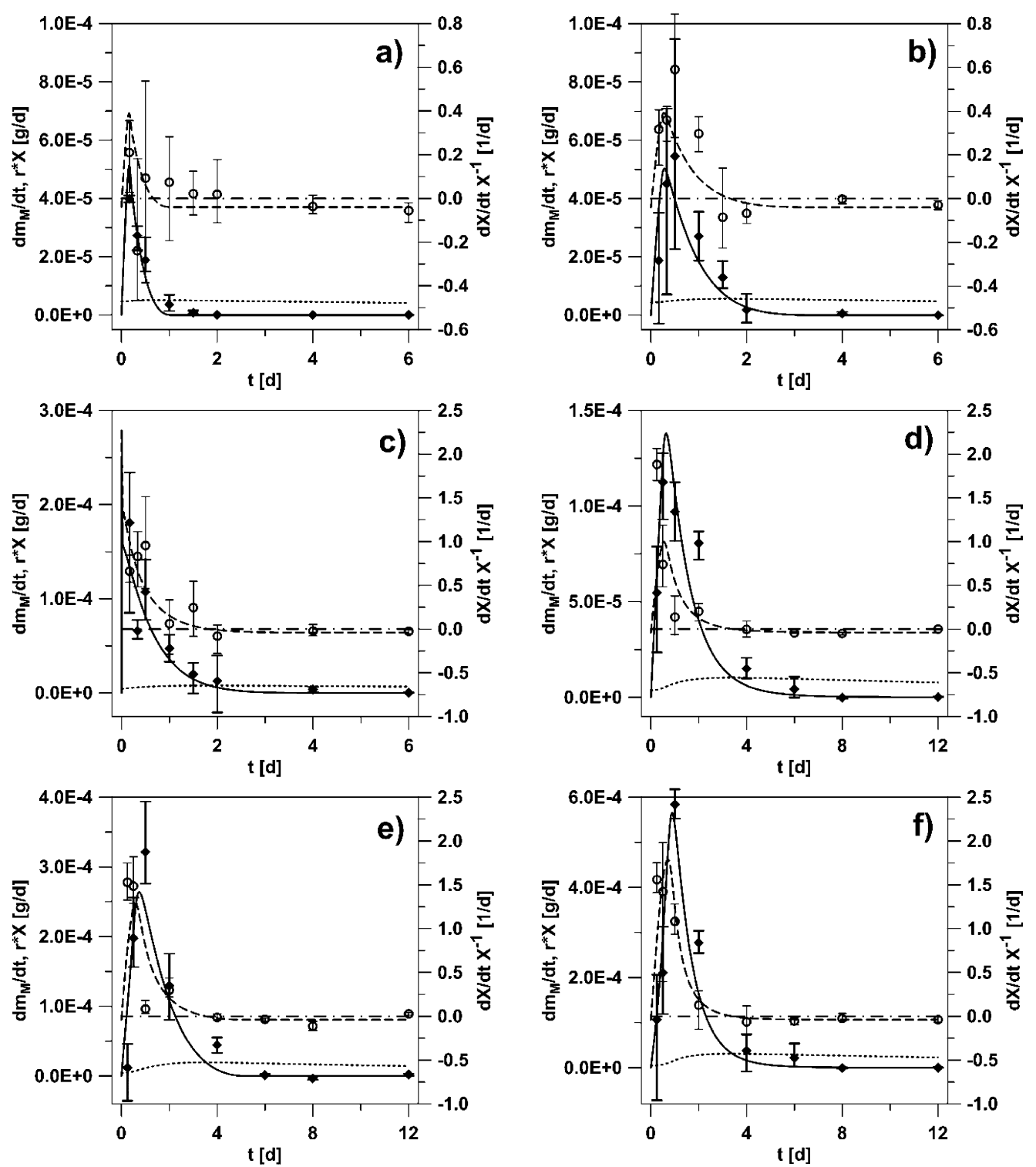

Figure 2. Experiments with $N$. pentaromativorans: phenanthrene consumption (degradation flux) $\mathrm{d} m_{\mathrm{M}} / \mathrm{d} t$ in $\mathrm{g} / \mathrm{d}(-\boldsymbol{-}$ ), microbial growth rate constant $\mathrm{d} X / \mathrm{d} t / X$ in $\mathrm{d}^{-1}$ (- - - - ) and maintenance $r X$ in $\mathrm{g} / \mathrm{d}(\cdots)$ versus time, measured (data points) vs modeled (curves). Point-dashed lines (-.-.-) indicates no growth $(\mathrm{d} X / \mathrm{d} t / X=0)$. Experiments with (a) $C_{0}=10 \mathrm{mg} \mathrm{L}^{-1}$, (b) $C_{0}=25 \mathrm{mg} \mathrm{L}^{-1}$, (c) $C_{0}=50 \mathrm{mg} \mathrm{L}^{-1},(\mathrm{~d}) C_{0}=100 \mathrm{mg} \mathrm{L}^{-1}$, (e) $C_{0}=200 \mathrm{mg} \mathrm{L}^{-1}$, (f) $C_{0}=400 \mathrm{mg} \mathrm{L}^{-1}$. Error bars indicate minimum and maximum (3 replicates).

calculations are based upon the assumption that only freely dissolved chemicals are subject to microbial degradation. For converting from protein mass to microbial mass, a fraction $f_{\text {m,prot }}$ of $0.55 \mathrm{~g}$ protein $\mathrm{g}^{-1}$ bacteria $(\mathrm{dw})$ was considered. ${ }^{32}$

The mass of substrate dissolved in water (index W) is increased by dissolution of solid PHE (index ph), and decreased by metabolism (index M):

$$
\frac{\mathrm{d} m_{\mathrm{W}}}{\mathrm{d} t}=+\frac{\mathrm{d} m_{\mathrm{ph}}}{\mathrm{d} t}-\frac{\mathrm{dm}_{M}}{\mathrm{~d} t}
$$

The freely dissolved concentration $C_{\mathrm{W}}\left(\mathrm{mg} \mathrm{L}^{-1}\right)$ is $m_{\mathrm{W}} / V$, where $V\left(\mathrm{~L}\right.$ or $\left.\mathrm{m}^{3}\right)$ is volume. The total PHE concentration in suspension is $C_{\mathrm{Sus}}=\left(m_{\mathrm{ph}}+m_{\mathrm{W}}\right) / V$. Experimentally observed lag phases were taken into consideration by introducing an inhibition factor $f_{\text {inh }}$ (described in Supporting Information).

All differential equations were solved numerically, both by an Euler one-step solution scheme realized as a Microsoft Excel spreadsheet and by the ODE45 solver (Runge-Kutta scheme with variable step size) within MATLAB R2013b. The correct implementation of the model was quality-controlled by comparing both numerical solutions and by verification against analytical (steady-state) solutions offered by the Best equation.

Determination of Kinetic Parameters. In the experiments, only microbial mass $X$ and substrate mass $m$ can be observed directly. The substrate metabolized by the microbes is related to bacterial growth via the yield $Y$ ( $\mathrm{g}$ bacteria $\mathrm{g}^{-1}$ substrate); it is used by microbes both for actual growth (with rate $\mu$ in $\mathrm{d}^{-1}$ ) and for maintenance needs $r$ ( $\mathrm{g}$ substrate $\mathrm{g}^{-1}$ bacteria $\left.\mathrm{d}^{-1}\right)$ of microbes decaying with rate $b\left(\mathrm{~d}^{-1}\right) .^{33}$ The experimentally observable growth rate constant is bacterial mass versus time per bacteria, $\mathrm{d} X(X \mathrm{~d} t)^{-1}$, and can be obtained from eq 3 as

$$
\frac{\mathrm{d} X}{X \mathrm{~d} t}=\frac{v_{\max } C_{\mathrm{W}}}{K_{\mathrm{M}}+C_{\mathrm{W}}} Y-r Y=v Y-r Y=\mu-b
$$


By rearranging, the "true" yield $Y$ ( $\mathrm{g}$ bacteria $\mathrm{g}^{-1}$ substrate) follows

$$
Y=\frac{\mu-b}{v-r}
$$

The experimentally derived yield $Y_{\exp }$ is the ratio of observed growth $\mathrm{d} X / \mathrm{d} t$ to change of substrate mass $\mathrm{d} m_{\mathrm{M}} / \mathrm{d} t$ :

$$
Y_{\text {exp }}=\frac{\mathrm{d} X}{\mathrm{~d} m_{\mathrm{M}}}
$$

This "experimental yield" is different from the true yield and varies with concentration due to the (concentration-independent) maintenance. Due to the complexity of the coupled model approach, the rapid change of numerical values, and the multitude of model parameters, least-squares fitting of predictions to the measured data was performed with manual expert adjustment of model parameters in an iterative procedure. Statistical data on the curve fits (root-mean-square errors, mean absolute errors, and coefficients of determination) are provided in Supplementary Table SI 2 for all simulations. In order to improve accuracy prior to determining $Y$, the death rate constant $b$ was found first from experiments with low substrate concentrations. The parameters $v_{\max }, K_{\mathrm{M}}, Y$, and $b$ were then determined iteratively for each bacterial strain until a combination was found that is optimal for all sets of experiments (initial nominal concentrations 10, 25, 50, 100, 200 , and $\left.400 \mathrm{mg} \mathrm{L}^{-1}\right)$. For an assessment of the dissolution kinetics, $f_{\mathrm{A}, 0}$ and $k_{\mathrm{agg}}$ (affecting the surface area of the PHE phase and thus the dissolution rate parameter values; see Supporting Information) were varied in order to explain the experimental observations. At low initial concentrations, a delay of metabolism (lag phase) was observed, and mass balance equations were adjusted with $f_{\text {inh,corr }}$ (leading to an adjustment of inhibition as a function of time).

\section{RESULTS}

The strains of bacteria applied in the experiments are characterized in detail as phenanthrene-degrading bacteria (Table 1). However, this characterization includes mostly physiologic and genetic descriptions and does not provide the basic growth and turnover kinetic data. The measured and simulated PHE suspension concentrations (left axis) and bacterial mass (right axis) of the experiments with $N$. pentaromativorans are shown in Figure 1. At all initial concentrations $\left(10,25,50,100,200\right.$, and $\left.400 \mathrm{mg} \mathrm{L}^{-1}\right)$, PHE is degraded virtually completely within the experimental period

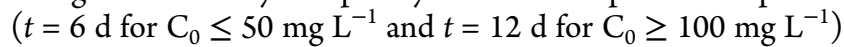
and faster at lower initial concentration. Rapid bacterial growth was observed from the increase of protein at the first day and up to 2 days with higher initial concentration, followed by decay after depletion of the substrate. Figure 2 shows the change of the parameters over time, i.e., measured and simulated PHE consumption (degradation flux) $\mathrm{d} m_{\mathrm{M}} / \mathrm{d} t$ (g $\left.\mathrm{d}^{-1}\right)$ plus (calculated) maintenance needs $r X\left(\mathrm{~g} \mathrm{~d}^{-1}\right)$ on the left axis and the bacterial growth rate constant $\mathrm{d} X / \mathrm{d} t / X\left(\mathrm{~d}^{-1}\right)$ on the right axis for the same experiments. Substrate consumption and growth are very closely related, peaking at the same time. With higher initial concentration, both peak later, and the substrate consumption is higher. In all samples, growth declines and growth rates become negative (below the line indicating no-growth conditions) as soon as the substrate is depleted. The fitted curves are within the measured range or very close (see Supplementary Table SI 2 for details on the statistics).

The measured and simulated PHE suspension concentrations (left axis) and protein concentrations (right axis) of the experiments with Sphingomonas sp. EPA505 are shown in Supplementary Figure SI1. The pattern is similar to the results in Figure 1, but the scatter of experimental data points is considerably higher. This is accompanied by less successful model fits (e.g., Supplementary Figure SIle). Supplementary Figure SI2 again shows the change of substrate and bacteria with time. At low initial concentrations, in particular for $25 \mathrm{mg}$ $\mathrm{L}^{-1}$ (Supplementary Figure SI2b), the substrate loss $\mathrm{d} m / \mathrm{d} t$ is higher and the growth is faster than for strain $N$. pentaromativorans. No advantage of Sphingomonas sp. is seen in experiments with high initial substrate concentrations (Supplementary Figure SI $2 \mathrm{f}$ vs Figure 2f).

Finally, the results for strain $S$. yanoikuyae are shown in Supplementary Figures SI3 and 4. This strain does not degrade PHE completely at the low initial concentrations (Supplementary Figure SI3a and b). Due to adsorption of the microbes to the crystals, the results for the protein concentration have a high scatter but seem to indicate no or little increase at these low concentrations, except for the first time period ( $t=0$ to $0.17 \mathrm{~d})$. The protein concentrations measured at $t=0$ are distinctly lower than for the following time periods. The fit of bacterial mass (Supplementary Figure SI3) is thus not very good. Starting with these low measured initial protein concentrations, the model does not reproduce the higher protein concentrations some hours later. Supplementary Figure SI4 shows the change of substrate and bacterial mass with time for strain S. yanoikuyae. Loss of mass quickly falls to zero, and growth becomes negative for the low initial concentrations (10 and $25 \mathrm{mg} \mathrm{L}^{-1}$, Supplementary Figure SI4a and b). At higher initial concentrations, metabolism and growth do not differ significantly from those of the two other strains.

All strains showed the typical growth curves with lag phases and exponential growth behavior instead of the limited growth mostly observed in previous experiments. The calibration of the model can yield these kinetic data and can also indicate differences in hydrophobic substrate mobilization. All strains showed yields and half-saturation constants within a similar range during growth on PHE (Table 2), which indicates similar metabolic pathways, but this is also due in part to the insensitivity of some data $\left(K_{\mathrm{M}}\right)$. Best curve fits for this scenario were obtained with $K_{\mathrm{M}}=0.1 \mathrm{mg} \mathrm{L}^{-1}, Y=0.21 \mathrm{~g}$ bact dw g $\mathrm{g}^{-1}, b$ $=0.04$ to $0.05 \mathrm{~d}^{-1}, v_{\max }=12 \mathrm{~g} \mathrm{~g}^{-1}$ bact $\mathrm{d}^{-1}$, both for strains $N$. pentaromativorans and Sphingomonas sp. EPA505, whereas for strain S. yanoikuyae a higher $v_{\max }$ of $18 \mathrm{~g} \mathrm{~g}^{-1}$ bact $\mathrm{d}^{-1}$ resulted from the curve fits (Table 2).

\section{DISCUSSION}

Growth experiments with bacteria plus water-insoluble and/or solid-state substrates are mostly biased by transport limitations and thus by limited bioavailability. ${ }^{20}$ For water-soluble substrates without mass-transfer limitations, such data are typically acquired using continuous chemostat cultures. However, this approach is not applicable to hydrophobic solid-state substrates with low water solubility due to the limitations of mass transfer at higher growth rates generally leading to limited non-exponential growth. ${ }^{19}$ Therefore, in the present work we provide a modeling approach to determine the real growth and yield parameters from turnover data measured 
Table 2. Model Parameters, Symbols, and Units ${ }^{a}$

\begin{tabular}{|c|c|c|c|c|}
\hline parameters & symbol & value & unit & ref \\
\hline \multicolumn{5}{|c|}{ Input Parameters } \\
\hline suspension volume & $V_{\text {Sus }}$ & 0.1 & $\mathrm{~L}$ & \\
\hline phenanthrene density & $\rho_{\mathrm{ph}}$ & 1100 & $\mathrm{~g} \mathrm{~L}^{-1}$ & 49 \\
\hline water solubility & $S$ & 1.15 & $\mathrm{mg} \mathrm{L}^{-1}$ & 49 \\
\hline microbial protein fract & $f_{\mathrm{m} \text {,prot }}$ & 0.55 & $\mathrm{~g}$ prot $\mathrm{g}^{-1}$ biomass & 32 \\
\hline mass transfer coefficient & $P$ & 1.58 & $\mathrm{~m} \mathrm{~d}^{-1}$ & 25 \\
\hline \multicolumn{5}{|c|}{ Fitted Parameters-Monod } \\
\hline \multicolumn{5}{|c|}{ Novosphingobium pentaromativorans } \\
\hline half-saturation const & $K_{\mathrm{M}}$ & 0.1 & $\mathrm{mg} \mathrm{L}^{-1}$ & \\
\hline yield & $Y$ & 0.21 & 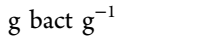 & \\
\hline $\begin{array}{l}\text { maximum growth } \\
\text { rate }\end{array}$ & $\mu_{\max }$ & 2.52 & $\mathrm{~d}^{-1}$ & \\
\hline decay rate const & $b$ & 0.05 & $\mathrm{~d}^{-1}$ & \\
\hline $\begin{array}{l}\text { maintenance } \\
\text { requirements }\end{array}$ & $r$ & 0.24 & $\mathrm{~g} \mathrm{~g}^{-1}$ bact $\mathrm{d}^{-1}$ & \\
\hline max removal rate & $v_{\max }$ & 12 & $\mathrm{~g} \mathrm{~g}^{-1}$ bact $\mathrm{d}^{-1}$ & \\
\hline \multicolumn{5}{|l|}{ Sphingomonas sp. EPA505 } \\
\hline half-saturation const & $K_{\mathrm{M}}$ & 0.1 & $\mathrm{mg} \mathrm{L} \mathrm{L}^{-1}$ & \\
\hline yield & $Y$ & 0.21 & $\mathrm{~g}_{\text {bact } \mathrm{g}^{-1}}$ & \\
\hline $\begin{array}{l}\text { maximum growth } \\
\text { rate }\end{array}$ & $\mu_{\max }$ & 2.52 & $d^{-1}$ & \\
\hline decay rate const & $b$ & 0.04 & $d^{-1}$ & \\
\hline $\begin{array}{l}\text { maintenance } \\
\text { requirements }\end{array}$ & $r$ & 0.20 & $\mathrm{~g} \mathrm{~g}^{-1}$ bact $\mathrm{d}^{-1}$ & \\
\hline max removal rate & $v_{\max }$ & 12 & $\mathrm{~g} \mathrm{~g}^{-1}$ bact $\mathrm{d}^{-1}$ & \\
\hline \multicolumn{5}{|l|}{ Sphingobium yanoikuyae } \\
\hline half-saturation const. & $K_{\mathrm{M}}$ & 0.1 & $\mathrm{mg} \mathrm{L}^{-1}$ & \\
\hline yield & $Y$ & 0.21 & 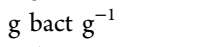 & \\
\hline $\begin{array}{l}\text { maximum growth } \\
\text { rate }\end{array}$ & $\mu_{\max }$ & 3.78 & $d^{-1}$ & \\
\hline decay rate const & $b$ & 0.04 & $\mathrm{~d}^{-1}$ & \\
\hline $\begin{array}{l}\text { maintenance } \\
\text { requirements }\end{array}$ & $r$ & 0.20 & $\mathrm{~g} \mathrm{~g}^{-1}$ bact $\mathrm{d}^{-1}$ & \\
\hline max removal rate & $v_{\max }$ & 18 & $\mathrm{~g} \mathrm{~g}^{-1}$ bact $\mathrm{d}^{-1}$ & \\
\hline
\end{tabular}

${ }^{a}$ fract: fraction; const: constant; max: maximal; corr: correction, bact: bacteria; prot: protein.

in batch experiments with PHE as model PAH substrate and several degrading strains.

For comparison of the strains, Figure 3 shows the substrate metabolism flux and the growth rate constants of the three degrader strains versus initial substrate concentrations. Figure $3 a-c$ represents the maximum fit and experimental value seen during the whole simulation period. The measured maximum loss and growth were typically very early in the experiment, therefore the results for $t=0.5 \mathrm{~d}$ (Figure $3 \mathrm{~d}-\mathrm{f}$ ) do not differ significantly. Measured metabolism and growth at $t=1 \mathrm{~d}$ (Figure $3 \mathrm{~g}-\mathrm{i}$ ) is lower than at $t=0.5 \mathrm{~d}$ for all strains. At $t=1 \mathrm{~d}$, substrate depletion at lower initial concentration has progressed, and negative growth rates are seen for the two initially fast-growing strains (Sphingomonas sp. EPA505 and $S$. yanoikuyae), accompanied by zero loss of PHE mass (Figure $3 \mathrm{~h}$ and i). The no-growth concentration can be found from setting $\mathrm{d} X / \mathrm{d} t$ in eq 5 to zero

$$
C_{\mathrm{W}, \text { no growth }}=\frac{b K_{\mathrm{M}}}{\mu_{\max }-b}
$$

and is close to $2 \mu \mathrm{g} \mathrm{L}^{-1}$ (corresponding to $10 \mathrm{nM}$ ). Such low values are quickly reached, due to vivid metabolism. Plots of $C_{\mathrm{W}}$ versus time are shown in Supplementary Figures SI5-7.
The provided data show that the apparent growth and degradation rates are only slightly different from the modeled ones and differ only slightly between the strains. Observed and modeled degradation flux $(\mathrm{d} m / \mathrm{d} t)$ increases at higher initial concentration of PHE, $C_{0}$, most pronouncedly for strain $N$. pentaromativorans and $S$. yanoikuyae, whereas for strain Sphingomonas sp. EPA505 there is only little change for $C_{0}$ above $200 \mathrm{mg} \mathrm{L}^{-1}$. Microbial growth rates $(\mathrm{dX} /(\mathrm{d} t X))$ show a peak at $C_{0}$ of 50 or $100 \mathrm{mg} \mathrm{L}^{-1}$ and are highest for strain $S$. yanoikuyae, followed by Sphingomonas sp. EPA505 and N. pentaromativorans (the maximum growth rates occur earlier than $t=0.5 \mathrm{~d}$ ). There is an obvious underestimation of growth (and, to some extent, also of metabolism) of the strains Sphingomonas sp. EPA505 and S. yanoikuyae at substrate concentrations $<100 \mathrm{mg} \mathrm{L}^{-1}$ (Supplementary Figure SIlb,c). This leads to the speculation that at the lowest substrate concentrations, these bacteria have mechanisms to make the substrate more available. Also, in Supplementary Figures SI1b,c and SI $3 \mathrm{a}-\mathrm{d}$, measured protein concentrations are higher than the calculated ones. However, there is also considerable scatter in the data.

In the experiments with Sphingomonas sp. EPA505 and $S$. yanoikuyae the substrate metabolism rate $\mathrm{d} m / \mathrm{d} t$ is far from linearly increasing with initial concentration. The comparison to the growth $\mathrm{d} X /(\mathrm{d} t X)$ leads to the conclusion that this decline cannot be explained by the half-saturation constant $K_{\mathrm{M}}$ but is due to the dissolution kinetics (see Supporting Information) and may also be due to toxic effects. All strains already reach their maximum growth at low initial substrate concentrations (though, as Figures 2 and Supplementary Figures SI2 and 4 show, only for a short time period), with little increase or even decrease for higher substrate concentrations.

Uptake from Solid State. Growth of bacteria with waterinsoluble and/or solid-state substrates can be biased by transport limitations and thus by limited bioavailability (see Supporting Information for discussion of dissolution kinetics). In real contaminated sites, sorption processes to solid matter and dissolution from NAPLs additionally limit the mass transfer and cause residual non-degradable concentrations. It is generally assumed that the transport and bacterial uptake of compounds occurs only via the water phase, and the model thus calculates this way (eq 1). There are some indications that transport may also occur directly from the organic phase or crystal to the cell membrane, e.g., Mycobacteria. ${ }^{34}$ However, the presented model describes the transfer and the following turnover processes sufficiently without considering direct transfer. The dissolution kinetics derived from the fit of parameters indicates differences between the strains, but these are small at least for dissolution during the first days when maximum metabolism occurs (variation of $f_{\mathrm{A}, 0}$ less than a factor 2; see Supporting Information). An interesting feature of the equations is, however, that direct uptake from crystals would not change the kinetics: the driver for uptake and metabolism is the chemical activity in solution, and the maximum activity that can be achieved is equivalent to the water solubility. This is at the same time the activity of the pure solid phase in contact to water. ${ }^{35}$ According to the equations, it is not the concentration of substrate in the dissolved state that limits degradation but the flux of substrate to the microbes. Thus, in order to increase their substrate supply, bacteria have no need to metabolize directly solid-phase substrate, for example, by pinocytotic endocytosis. The right strategy for microbes to increase the flux 

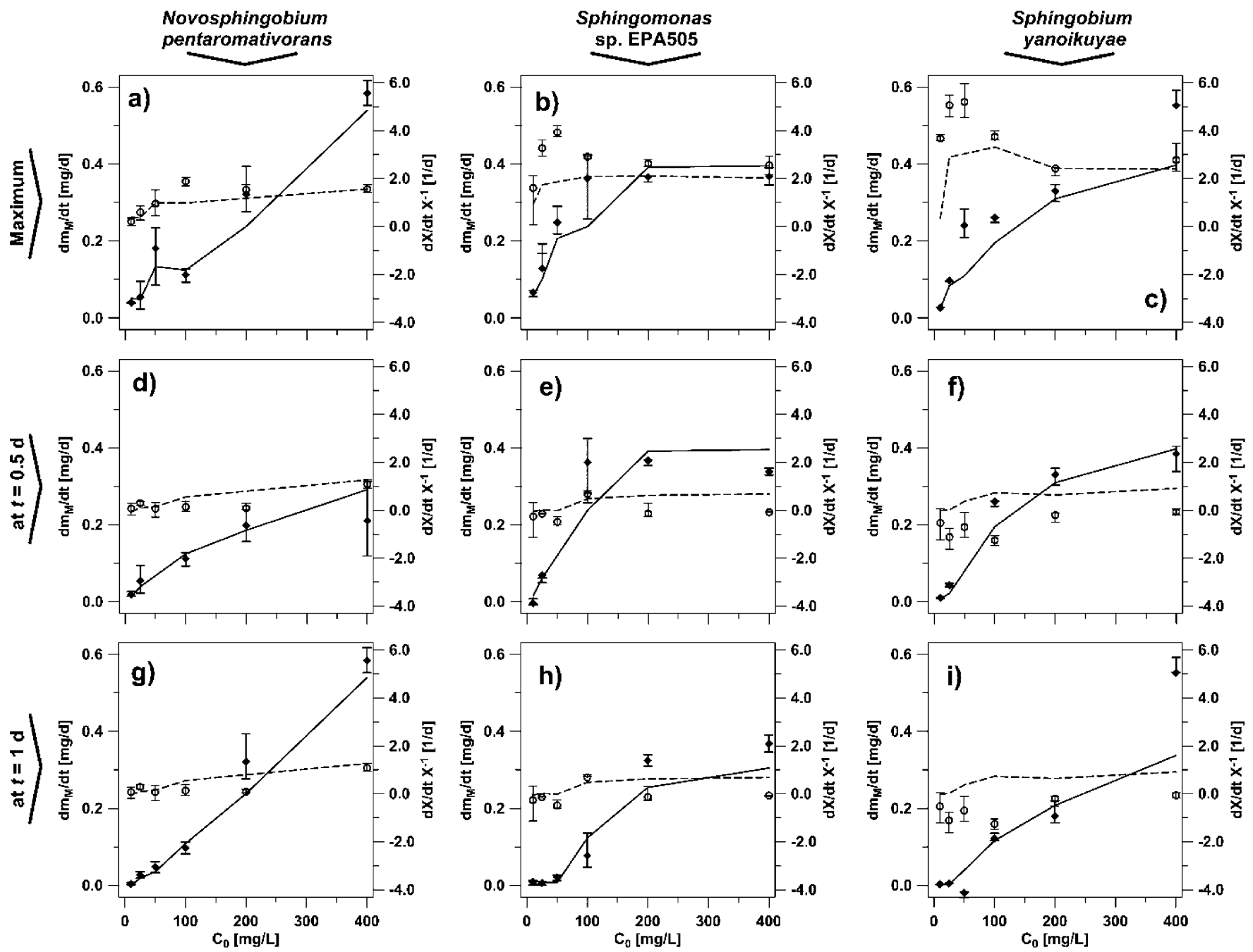

Figure 3. Degradation flux $\mathrm{d} m_{\mathrm{M}} / \mathrm{d} t\left(--_{-}\right)$and microbial growth rate $\mathrm{d} X / \mathrm{d} t / X\left(-\mathrm{O}_{-}-\right)$as a function of the initial concentration $C_{0}$ for the three investigated strains. Measured (data points) vs modeled (curves). (a-c) Maximum values, $(\mathrm{d}-\mathrm{f})$ values at time $t=0.5$, $(\mathrm{g}-\mathrm{i})$ values at $t=1 \mathrm{day}$. Strains: $(\mathrm{a}, \mathrm{d}, \mathrm{g})=$ N. pentaromativorans; $(\mathrm{b}, \mathrm{e}, \mathrm{h})=$ Sphingomonas sp. EPA505; $(\mathrm{c}, \mathrm{f}, \mathrm{i})=$ S. yanoikuyae. Error bars indicate minimum and maximum $(3$ replicates).

to their enzymes is to increase the dissolution kinetics. This can be achieved by various means, e.g., increase of surface or mobilization by exudates or biosurfactants or perhaps by mycolic acids. This theoretical conclusion is confirmed for alkanes by experiments of Yoshida et al. (cited in ref 20) that compare the growth rates of Candida tropicalis on liquid and vapor $n$-hexadecane in two different fermenters. In both cases, the chemical activity is at maximum (but either in gas phase or in liquid phase), and the specific growth rate of the microorganisms does not differ. The conclusion of the authors was that microbial hydrocarbon uptake by direct contact with the liquid hydrocarbon is negligible.

Comparison to Other Findings. Using solid anthracene as substrate for Mycobacterium sp. LB501T, Wick et al. fitted a yield of $15,500 \mathrm{mg}$ protein $\mathrm{mol}^{-1} \mathrm{~h}^{-1}$ for suspended bacteria and of 19,200 mg protein $\mathrm{mol}^{-1} \mathrm{~h}^{-1}$ for total biomass. ${ }^{18}$ With molar mass $M$ of anthracene and $0.55 \mathrm{~g}$ protein $\mathrm{g}^{-1}$ bacteria (dw) this corresponds to a yield $Y$ of 0.158 and $0.196 \mathrm{~g}$ biomass $\mathrm{g}^{-1}$ substrate $\mathrm{d}^{-1}$. A decay rate $b$ of $0.017 \mathrm{~d}^{-1}$ was derived from the zero-growth phase of batches and by using total biomass, while calculations for only the crystal-bound biomass and nonlinear model fit gave $0.048 \mathrm{~d}^{-1}$, corresponding to a maintenance need $r$ of $0.245-0.303 \mathrm{~g} \mathrm{~g}^{-1} \mathrm{~d}^{-1}$. The other parameters were $K_{\mathrm{M}}=2.4 \times 10^{-4} \mathrm{~mol} \mathrm{~m}^{-3}\left(0.0428 \mathrm{mg} \mathrm{L}^{-1}\right)$ and $v_{\max }$ $=7.8 \times 10^{-6} \mathrm{~mol} \mathrm{mg}^{-1}$ protein $\mathrm{h}^{-1}\left(18.4 \mathrm{~g}\right.$ substrate $\mathrm{g}^{-1}$ biomass $\mathrm{d}^{-1}$ ), from which $\mu_{\max }$ values of $2.9-3.59 \mathrm{~d}^{-1}$ result. In contrast, the experimentally determined $\mu_{\max }$ from growth in the exponential state was only $0.864 \mathrm{~d}^{-1} \cdot{ }^{18}$ As in our study, growth and metabolism of the test organisms were limited by the substrate flux to the organisms. Comparison of these values for anthracene with those from our study for PHE (Table 2, $K_{\mathrm{M}}$ $=0.1 \mathrm{mg} \mathrm{L}^{-1}, v_{\max }=12$ to $18 \mathrm{~g} \mathrm{~g}^{-1} \mathrm{~d}^{-1}, Y=0.21 \mathrm{~g} \mathrm{~g}^{-1}, b=0.04$ $-0.05 \mathrm{~d}^{-1}$ ) makes obvious that the data from the non-linear fits of the different experiments agree with each other quite closely. This is remarkable because it means that all four strains, including Mycobacterium sp. LB501T, have very similar kinetic properties. In particular, S. yanoikuyae with $v_{\max }$ values of 18 $\mathrm{g} \mathrm{g}^{-1}$ bact $\mathrm{d}^{-1}$ shows growth and metabolism kinetics almost identical that of to Mycobacterium sp. LB501T. S. yanoikuyae was isolated from a marine contaminated site. ${ }^{36}$ The values for $K_{\mathrm{M}}$ differ more, but $K_{\mathrm{M}}$ is rather insensitive, and moderate variations of this parameter do not change the simulation results. However, the $K_{\mathrm{M}}$ values derived here are also surprisingly similar to the half-saturation constants of Aitken 
et al., who found for 11 isolates from PAH contaminated sites $K_{\mathrm{M}}$ values between 0.014 and $0.38 \mathrm{mg} \mathrm{L}^{-1}$, with median at $0.155 \mathrm{mg} \mathrm{L}^{-1} .14$

Ortega-Calvo and Gschwend analyzed biodegradation experiments where oxygen supply and desorption of PAH from black carbon materials were limiting pyrene degradation by Mycobacterium gilvum. ${ }^{37}$ Low levels of oxygen were sufficient for removal. The measured pyrene concentrations reached a quasi-steady-state balancing desorption and removal. The kinetics followed Michaelis-Menten and was determined by fit of a calibrated mass-balance model. $K_{M}$ values obtained were a factor of 100 lower than for PHE $(6 \mathrm{nM}$, corresponding to $\left.1.2 \times 10^{-3} \mathrm{mg} \mathrm{L}^{-1}\right)$.

In general, the $K_{\mathrm{M}}$ values of around $0.1 \mathrm{mg} \mathrm{L}^{-1}$ determined in the present study by inverse modeling of the PHE degradation are in the range of other $\mathrm{PAH}^{14,18}$ but are 2-3 orders of magnitude higher than for other monoaromatic substrates. ${ }^{38}$ The yields of $0.21 \mathrm{~g}$ biomass $\mathrm{g}$ substrate ${ }^{-1}$ observed are in the range of values observed for other aromatic hydrocarbons. ${ }^{38}$

Other Model Approaches. The Best equation ${ }^{15,39,15,18,19}$ balances diffusive flux to the bacterium with metabolic flux; both can limit substrate degradation. A shortcoming of the concept is that it requires steady-state, i.e., equal dissolution and metabolism kinetics constant over time. The dynamic model described above can mimic these conditions by starting with initial conditions at steady-state and then yields identical results. This was used to mathematically verify the model and its implementation.

An elegant and comparatively simple equation for the kinetics of microbial degradation of poorly soluble organics was developed and applied by Yassine et al. ${ }^{20}$ The model assumes that biodegradation takes place in the aqueous phase and that, like here, growth kinetics follow Monod kinetics with decay term. The approach was applied to rather insoluble petroleum diesel alkanes (C10-C24) and fatty acid methyl esters. Thus, it was also assumed that the dissolution is fast compared to biodegradation, and aqueous concentrations were set to constant (at solubility). This allowed an analytical solution of the equation system.

Turnover kinetics was influenced by the poor water solubility of the substrate and probably below maximum. We found an actual turnover of only 0.24 to $0.48 \mathrm{~g} \mathrm{~g}^{-1} \mathrm{~d}^{-1}$, which is low, presumably because substrate solubility was much lower than the half-saturation concentration. Maximum stoichiometric yield coefficients $Y$ were about $1.6 \mathrm{~g} \mathrm{~g}^{-1}$. The decay rate constants $b$ calculated from controls were at 0.023 and 0.026 $\mathrm{d}^{-1}$, which is about half of the values found in our study and by Wick et al. ${ }^{18}$ Yassine et al. ${ }^{20}$ pointed out that conventional Monod-type kinetic models for poorly soluble organic compounds are of little practical value; actual utilization rates may be orders of magnitude lower because these substrates do not dissolve in sufficient quantities. A couple of other earlier model approaches were reviewed in Yassine et al. ${ }^{20}$ and we refer to this.

Limitations. The approach presented in this study has limitations. First of all, the experimental design was intended to create nonlimited growth conditions for the bacterial strains by providing sufficient substrate. Due to the hydrophobicity of PHE, microcrystals were used that dissolve over time. This obviously succeeded in providing sufficient substrate for unlimited growth of all strains, but only for the first period of the experiments. After about 1 day, bacterial numbers had increased so much, and smaller crystals had dissolved, so that substrate availability nevertheless became limiting. Another disadvantage of the approach was that the use of crystals does not lead to controlled, constant concentrations in dissolved state, and (small) variations in the dissolution kinetics of crystals may also have appeared. Additional parameters for the dissolution kinetics had to be introduced, which led to additional uncertainty and provided some problems in the calibration.

For the model approach, only two experimental parameters could directly be observed: total substrate concentration in suspension and protein density. These two variables were also the state variables of the model. Of the several input parameters into the model (Table 2), some were unknown and had to be fitted by model calibration. The kinetic parameters of the bacteria, i.e., $v_{\max } Y$, and $b$, were also the target parameters of the study, and no independent control or direct measurement is feasible. The parameter $K_{\mathrm{M}}$ affects metabolism and growth rates only at low concentrations and was rather insensitive for the simulations. Two additional parameters were necessary for improved simulation of the observations, which we consider to describe the dissolution kinetics $\left(f_{\mathrm{A}}, k_{\mathrm{agg}}\right)$. In principle, the observed reduction of metabolism during the progress of the experiment could as well have been an effect of the accumulation of metabolites, leading to inhibition of the strains and thus less substrate turnover and reduced bacterial growth. However, with our analytical approach we did not find any evidence for primary oxidation products of PHE, which may be toxic.

The model was applied to well-mixed vessels without spatial differences. Subsequently, a set of ordinary differential equations was solved. In real environmental systems, such as soils and sediments, conditions are not homogeneous and not well-mixed, and such spatial dependencies may play a crucial role. ${ }^{40}$ Advection processes (water flow) may also impact the compound transport to the organisms. Moreover, in real systems, parameters affecting the growth such as water content and temperature are variable and different from the conditions in laboratory. This may lead to suboptimal growth conditions, and the growth rates determined in laboratory experiments are perhaps not realistic for such environmental conditions.

Implications of the Model. In the present work we provide new and improved experimental kinetic data for three Gram-negative PHE-degrading strains well-known from the literature, isolated from various contaminated sites. The new dynamic model for desorption and metabolism describes mass transfer of the substrate, taking into consideration chemical activity, sorption and dissolution processes, metabolism, and growth as well as cell maintenance and decay processes simultaneously in non-steady state.

Moreover, provided that the equations describe the kinetic data correctly and the initial conditions of the system are known, model simulations may predict the residual concentrations. The approach is also valid for compounds that are generally biodegradable with formation of biomass; even the special case of cometabolic degradation can be integrated. The model offers distinct prospective power for the assessment of residual non-degradable concentrations to be expected after various treatment options of contaminated soils and remediation measures. We plan to describe this in a future article in detail.

A surprising outcome of the simulation is that variations of the initial amount and of kinetic data of the degrader bacteria do not strongly affect the overall turnover. As long as the 
dissolved concentration is sufficiently high the degrader strains will grow, until a balance between dissolution of substrate and bacterial metabolism is reached. This balance was reached within a day or less in all set-ups. Thus, for longer time periods, the amount of PAH ultimately degraded depends more on the ad/desorption rates than on the Monod and MichaelisMenten parameters.

\section{ASSOCIATED CONTENT}

\section{S Supporting Information}

More detailed equations for crystal surface and initial lag phases in the mathematical model; details of the determination of kinetic parameters, statistical data on curve fits, and the discussion of dissolution kinetics. This material is available free of charge via the Internet at http://pubs.acs.org.

\section{AUTHOR INFORMATION}

\section{Corresponding Author}

*Phone: +49 (89) 289-25869. Fax: +49 (89) 289-25841. Email: arno.rein@tum.de.

\section{Present Address}

${ }^{\perp}$ Chair of Hydrogeology, Technical University of Munich, Arcisstr. 21, 80333 Munich, Germany.

\section{Author Contributions}

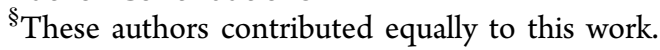

\section{Author Contributions}

"These authors contributed equally to this paper and to the organization of the project.

\section{Notes}

The authors declare no competing financial interest.

\section{ACKNOWLEDGMENTS}

This research project was financially supported by the European Union (Project "Molecular Approaches and MetaGenomic Investigations for optimizing Clean-up of PAH contaminated sites, MAGICPAH, Grant Agreement No. 245226) and by the Helmholtz Centre for Environmental Research UFZ. The unified model with description is available in a public version at http://www.magicpah.org/links/ or http://homepage.env.dtu.dk/stt/.

\section{REFERENCES}

(1) Cerniglia, C. E.; Heitkamp, M. A. Microbial metabolism of polycyclic aromatic hydrocarbons $(\mathrm{PAH})$ in the aquatic environment. In Metabolism of Polycyclic Aromatic Hydrocarbons in the Aquatic Environment; Varanasi, U., Ed.; CRC Press: Boca Raton, 1989; pp 4168.

(2) Kästner, M. Degradation of aromatic and polyaromatic compounds. In Biotechnology, 2nd ed.; Environmental Processes; Rehm, H.-J., Reed, G., Pühler, A., Stadler, P., Eds.; Wiley-VCH: Weinheim, 2000; Vol. 11b, pp 211-239.

(3) Cerniglia, C. E. Microbial metabolism of polycyclic aromatic hydrocarbons. Adv. Appl. Microbiol. 1984, 30, 31-71.

(4) Cerniglia, C. E. Biodegradation of polycyclic aromatic hydrocarbons. Biodegradation 1992, 3, 351-368.

(5) Cerniglia, C. E. Fungal metabolism of aromatic hydrocarbons. In Microbial Degradation of Natural Products; Winkelmann, G., Ed.; VCH: Weinheim, 1992; pp 193-217.

(6) Evans, W. C.; Fernley, H. N.; Griffith, E. Oxidative metabolism of phenanthrene and anthracene by soil pseudomonads. The ring-fission mechanism. Biochem. J. 1965, 95, 819-831.

(7) Hammel, K. E. Organopollutant degradation by ligninolytic fungi. In Microbial Transformation and Degradation of Toxic Organic Chemicals; Young, L. Y., Cerniglia, K. E., Eds.; Wiley Series in
Ecological and Applied Microbiology; Wiley-Liss Inc.: New York, 1995; pp 331-346.

(8) Juhasz, A. L.; Naidu, R. Bioremediation of high molecular weight polycyclic aromatic hydrocarbons: a review of the microbial degradation of benzo $[a]$ pyrene. Int. Biodeterior. Biodegrad. 2000, 45, $57-88$.

(9) Kanaly, R. A.; Harayama, S. Biodegradation of high-molecularweight polycyclic aromatic hydrocarbons by bacteria. J. Bacteriol. 2000, 182, 2059-2067.

(10) Lu, X. Y.; Zhang, T.; Fang, H. H. P. Bacteria-mediated PAH degradation in soil and sediment. Appl. Microbiol. Biotechnol. 2011, 89, 1357-1371.

(11) Sanglard, D.; Leisola, M. S. A.; Fiechter, A. Role of extracellular ligninases in biodegradation of benzo(a)pyrene by Phanerochaete chrysosporium. Enzyme Microb. Technol. 1986, 8, 209-213.

(12) Sutherland, J. B.; Rafil, F.; Khan, A. A.; Cerniglia, C. E. Mechanisms of polycylic aromatic hydrocarbon degradation. In Microbial Transformation and Degradation of Toxic Organic Chemicals; Young, L. Y., Cerniglia, C. E., Eds.; Wiley-Liss Inc.: New York, 1995; pp 269-306.

(13) Pothuluri, J. V.; Cerniglia, C. E. Microbial metabolism of polycyclic aromatic hydrocarbons. In Biological Degradation of Toxic Chemicals; Chaudhry, G. R., Ed.; Dioscorides Press: Portland, OR, 1994; pp 92-123.

(14) Aitken, M. D.; Stringfellow, W. T.; Nagel, R. D.; Kazunga, C.; Chen, S. H. Characteristics of phenanthrene-degrading bacteria isolated from soils contaminated with polycyclic aromatic hydrocarbons. Can. J. Microbiol. 1998, 44, 743-752.

(15) Bosma, T. N. P.; Middeldorp, P. J. M.; Schraa, G.; Zehnder, A. J. B. Mass transfer limitation of biotransformation: Quantifying bioavailability. Environ. Sci. Technol. 1997, 31, 248-252.

(16) Guha, S.; Jaffe, P. R. Determination of Monod kinetic coefficients for volatile hydrophobic organic compounds. Biotechnol. Bioeng. 1996, 50, 693-699.

(17) Stringfellow, W. T.; Aitken, M. D. Comparative physiology of phenanthrene degradation by two dissimilar pseudomonads isolated from a creosote-contaminated soil. Can. J. Microbiol. 1994, 40, 432438.

(18) Wick, L. Y.; Colangelo, T.; Harms, H. Kinetics of mass transferlimited bacterial growth on solid PAHs. Environ. Sci. Technol. 2001, 35, 354-361.

(19) Volkering, F.; Breure, A. M.; Sterkenburg, A.; Vanandel, J. G. Microbial degradation of polycyclic aromatic hydrocarbons - Effect of substrate availability on bacterial growth kinetics. Appl. Microbiol. Biotechnol. 1992, 36, 548-552.

(20) Yassine, M. H.; Suidan, M. T.; Venosa, A. D. Microbial kinetic model for the degradation of poorly soluble organic materials. Water Res. 2013, 47, 1585-1595.

(21) Robinson, J. A.; Tiedje, J. M. Nonlinear estimation of Monod growth kinetic parameters from a single substrate depletion curve. Appl. Environ. Microbiol. 1983, 45, 1453-1458.

(22) Trapp, S.; Rein, A. Predictive model for PAH degradation and residue formation related to bioavailability. Magic PAH Deliverable 23, 2012; available at http://homepage.env.dtu.dk/stt/; last retrieved 1 Dec 2013.

(23) Kästner, M.; Nowak, K. M.; Miltner, A.; Trapp, S.; Schäffer, A. Classification and modelling of non-extractable residue (NER) formation of xenobiotics in soil - a synthesis. Crit. Rev. Environ. Sci. Technol. 2013, DOI: 10.1080/10643389.2013.828270.

(24) Marchal, G.; Smith, K. E. C.; Rein, A.; Winding, A.; de Jonge, L. W.; Trapp, S.; Karlson, U. G. Impact of activated carbon, biochar and compost on the desorption and mineralization of phenenthrene in soil. Environ. Pollut. 2013, 181, 200-210.

(25) Marchal, G.; Smith, K. E. C.; Rein, A.; Winding, A.; Trapp, S.; Karlson, U. G. Comparing the desorption and biodegradation of low concentrations of phenanthrene sorbed to activated carbon, biochar and compost. Chemosphere 2013, 90, 1767-1778, DOI: 10.1016/ j.chemosphere.2012.07.048. 
(26) DSMZ Mineral Medium (Brunner) with Vitamins. http://www. dsmz.de/microorganisms/medium/pdf/DSMZ_Medium462.pdf; accessed 13 Dec 2013.

(27) Mutnuri, S.; Vasudevan, N.; Kaestner, M. Degradation of anthracene and pyrene supplied by microcrystals and non-aqueousphase liquids. Appl. Microbiol. Biotechnol. 2005, 67, 569-576.

(28) David, F.; Klee, M. S. Fast analysis of polynuclear aromatic hydrocarbons using Agilent Low Thermal Mass (LTM) GC/MS and capillary flow technology QuickSwap for backflush. Appl. Note Environ. 5990-3451EN; Agilent Technolgies: Santa Clara, CA, 2009.

(29) Cornish-Bowden, A. Fundamentals of Enzyme Kinetics; Portland Press: London, U.K., 1995.

(30) Mayer, P.; Fernqvist, M. M.; Christensen, P. S.; Karlson, U.; Trapp, S. Enhanced diffusion of polycyclic aromatic hydrocarhons in artificial and natural aqueous solutions. Environ. Sci. Technol. 2007, 41, $6148-6155$

(31) Koch, A. L. Microbial physiology and ecology of slow growth. Microbiol. Mol. Biol. Rev. 1997, 61, 305-318.

(32) Tchobanoglous, G.; Burton, F. L.; Stensel, H. D. Wastewater Engineering, Treatment and Reuse, 4th ed.; McGraw-Hill: Boston, 2004.

(33) van Uden, N. Transport-limited growth in the chemostat and its competitive inhibition; a theoretical treatment. Archiv für Mikrobiologie 1967, 58, 145-154.

(34) Wick, L. Y.; Pasche, N.; Bernasconi, S. M.; Pelz, O.; Harms, H. Characterization of multiple-substrate utilization by anthracenedegrading Mycobacterium frederiksbergense LB501T. Appl. Environ. Microbiol. 2003, 69, 6133-6142.

(35) Trapp, S.; Franco, A.; Mackay, D. Activity-based concept for transport and partitioning of ionizing organics. Environ. Sci. Technol. 2010, 44, 6123-6129.

(36) Gibson, D. T.; Roberts, R. L.; Wells, M. C.; Kobal, V. M. Oxidation of biphenyl by a Beijerinckia species. Biochem. Biophys. Res. Commun. 1973, 50, 211-219.

(37) Ortega-Calvo, J. J.; Gschwend, P. M. Influence of low oxygen tensions and sorption to sediment Black Carbon on biodegradation of pyrene. Appl. Environ. Microbiol. 2010, 76, 4430-4437.

(38) Ostendorf, D. W.; Schoenberg, T. H.; Hinlein, E. S.; Long, S. C. Monod kinetics for aerobic biodegradation of petroleum hydrocarbons in unsaturated soil microcosms. Environ. Sci. Technol. 2007, 41, 23432349.

(39) Koch, A. L. Diffusion. The crucial process in many aspects of the biology of bacteria. Adv. Microb. Ecol. 1990, 11, 37-70.

(40) Rosenbom, A. E.; Binning, P. J.; Aamand, J.; Deschesne, A.; Smets, B. F.; Johnsen, A. R. Does microbial centimeter-scale heterogeneity impact MCPA degradation in and leaching from a loamy agricultural soil? Sci. Total Environ. 2014, 472, 90-98.

(41) Khan, A. A.; Wang, R. F.; Cao, W. W.; Franklin, W.; Cerniglia, C. E. Reclassification of a polycyclic aromatic hydrocarbonmetabolizing bacterium, Beijerinckia sp strain B1, as Sphingomonas yanoikuyae by fatty acid analysis, protein pattern analysis, DNA-DNA hybridization, and $16 \mathrm{~S}$ ribosomal DNA sequencing. Int. J. Syst. Bacteriol. 1996, 46, 466-469.

(42) Kiyohara, H.; Sugiyama, M.; Mondello, F. J.; Gibson, D. T.; Yano, K. Plasmid involvement in the degradation of polycyclic aromatic hydrocarbons by a Beijerinckia species. Biochem. Biophys. Res. Commun. 1983, 111, 939-945.

(43) Nohynek, L. J.; Nurmiaho-Lassila, E. L.; Suhonen, E. L.; Busse, H. J.; Mohammadi, M.; Hantula, J.; Rainey, F.; Salkinoja-Salonen, M. S. Description of chlorophenol-degrading Pseudomonas sp. strains KF1(T), KF3, and NKF1 as a new species of the genus Sphingomonas, Sphingomonas subarctica sp. nov. Int. J. Syst. Bacteriol. 1996, 46, 10421055.

(44) Mueller, J. G.; Chapman, P. J.; Blattmann, B. O.; Pritchard, P. H. Isolation and characterization of a fluoranthene-utilizing strain of Pseudomonas paucimobilis. Appl. Environ. Microbiol. 1990, 56, 10791086.

(45) Mueller, J. G.; Chapman, P. J.; Pritchard, P. H. Action of a fluoranthene-utilizing bacterial community on polycyclic aromatic hydrocarbon components of creosote. Appl. Environ. Microbiol. 1989, 55, 3085-3090.

(46) Mueller, J. G.; Chapman, P. J.; Pritchard, P. H. Creosotecontaminated sites - their potential for bioremediation. Environ. Sci. Technol. 1989, 23, 1197-1201.

(47) Luo, Y. R.; Kang, S. G.; Kim, S. J.; Kim, M. R.; Li, N.; Lee, J. L.; Kwon, K. K. Genome sequence of benzo(a)pyrene-degrading bacterium Novosphingobium pentaromativorans US6-1. J. Bacteriol. 2012, 194, 907-907.

(48) Sohn, J. H.; Kwon, K. K.; Kang, J. H.; Jung, H. B.; Kim, S. J. Novosphingobium pentaromativorans sp. nov., a high-molecular-mass polycyclic aromatic hydrocarbon-degrading bacterium isolated from estuarine sediment. Int. J. Syst. Evol. Microbiol. 2004, 54, 1483-1487, DOI: 10.1099 /ijs.0.02945-0.

(49) Rippen, G. Handbuch Umweltchemikalien: Stoffdaten, Prüfverfahren, Vorschriften; Ecomed Verlagsgesellschaft: Landsberg am Lech, 1990. 